\title{
Determination of Plasma Progesterone, Estrone, and Estradiol-17 $\beta$ by Radioimmunoassay
}

\section{Takayoshi AOKI}

The Genter for Health Care of Aichi, Nagoya, Japan

An efficient radioimmonoassay system for simultaneous measurement of plasma progesterone, estrone, and estradiol-17 $\beta$ has been developed using the antisera produced by the immunization of rabbits with progesterone-20-(0-carboxymethyl)-oxime BSA and estradiol-17 $\beta$-succinyl BSA. One ml aliquots of plasma from nonpregnant women were extracted once with $8 \mathrm{ml}$ of ether and thin layer chromatographed (BAKER-FLEX Silica Gel IB) in the solvent system of chloroform/ethanol $19: 1$, and the fractions of progesterone, estrone, and estradiol-17 $\beta$, which were definitely separated from the cross-reacting steroids, were then radioimmunoassayed. Separation of the free from the antibody-bound radioactivity was achieved by ammonium sulfate precipitation. The sensitivity of the radioimmunoassay was $10 \mathrm{Pg} / \mathrm{ml}$ for all three steroids assayed. Only four hours are required for the determination of 5 plasma samples (15 fractions), and 50 samples (150 fractions) can be determined by a single worker in 16 hours. (See pp. 612 618) 


\title{
Radioimmunoassay による血漿中 Progesterone, Estrone, Estradiol-17 $\beta$ の 測 定
}

\author{
愛知県総合保健センター成人病䧐断部 \\ 青木孝允
}

（胎和147年10月16日受付）

臨床に於て，非妊婦血中の progesterone, estrone, estradiol-17 $\beta$ を比較的容易に測定せんとする目的 で, 3 ホルモンの radioimmunoassay（RIA）を試みた。 progesterone-20-oxime BSA 及び estradiol$17 \beta$-succinyl BSA をウサギに免废して得た抗体は，目的とするステロイド以外とも交叉反応を示す為， 検体を予め薄首クロマトグラフィーで 1 回精製した. RIA の感度は $10 \mathrm{Pg} / \mathrm{ml}$ で極めてすぐれており， 全操作を通じた能率面でも略々满足出来るものである.

\section{緒言}

医学の進歩と共に，診断及び治療面に於けるステロイドホルモン測定の重要性は近年急速に高まつてきた. 1969年 estradiol-17 $\beta$ の radioimmunoassay (RIA) ${ }^{1)}$ が報告されて以来, 此の RIA によるステロイド測定 法は其の迅速性と高い感度が注目され，新しい臨床検查法として実用化が期待されている。

著者は産婦人科部療面で特に要望の多い血中 progesterone $(P)$, estrone $\left(E_{1}\right)$, estradiol-17 $\beta\left(E_{2}\right)$ の測定 を RIA で比較的能率よく行う方法を確立したので報告する。

\section{実験方法並びに結果}

\section{1. 抗血清の作製}

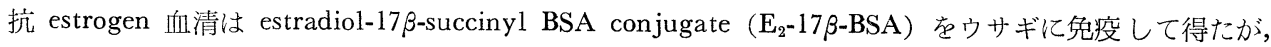
其の詳細は既に報告した methyl) oxime BSA conjugate (P-20-BSA) t $0.01 \mathrm{M}$ phosphate buffer, $\mathrm{pH} 7.4 \mathrm{lml}$ 当り $2 \mathrm{mg} の$ 割合 で溶解し，等量の Freund's complete adjuvant を加えて emulsion とし，2 羽のウサギ（約 $3.5 \mathrm{~kg}$ 成熟 雌）の背部皮下数個所に分けて注射した。免疫の過程を Table 1. 亿示す. 2 週間隔で 7 回免疫した Rabbit A. から9,200×の力価を有する抗 P-20-BSA を得た．力価の決定方法は，8×120 mm の硝子製試験管 (同し 規格の試験管を後述する RIA に使用した）に bovine $\gamma$-globulin t $1 \%$ の割合で含有する 1/15M phos-

Table 1. Immunization of rabbits by multiple subcutaneous injections of progesterone-20oxime-BSA. Rabbit A produced a satisfactory antiserum following 6 injections at 2 week intervals and a single booster.

\begin{tabular}{l|c|c|c|c|c|c|c|c|c|c}
\hline \hline $\begin{array}{l}\text { Injection } \\
\text { Animals }\end{array}$ & (1) & (2) & (3) & titration & (4) & (5) & titration & (6) & (7) & titration \\
\hline \hline Rabbit A & $5 \mathrm{mg}$ & $5 \mathrm{mg}$ & $5 \mathrm{mg}$ & $32 \times$ & $5 \mathrm{mg}$ & $3 \mathrm{mg}$ & $850 \times$ & $3 \mathrm{mg}$ & $\begin{array}{c}3 \mathrm{mg} \\
\text { booster }\end{array}$ & $9,200 \times$ \\
Rabbit B & $5 \mathrm{mg}$ & $4 \mathrm{mg}$ & $2 \mathrm{mg}$ & $96 \times$ & $2 \mathrm{mg}$ & injured & & & & \\
\hline
\end{tabular}


phate buffer, pH 7.4 (以下抗血清の稀釈には此の液を用いた) $0.1 \mathrm{ml}$ で抗 P-20-BSA を段階稀秎した系列 を作り，これに2.5\%エタノールを含む1/15M phosphate buffer, pH 7.4 (放射性ステロイド，標準ステロ イド，検体の溶解にはすべて此の腹を用いた。 以下単に buffer と略）に溶解した progesterone-1, $2-{ }^{3} \mathrm{H}$ $(50.3 \mathrm{Ci} / \mathrm{mM}) \quad 0.02 \mu \mathrm{Ci}, 0.1 \mathrm{ml}$ と buffer $0.2 \mathrm{ml}$ を加え， $37^{\circ} \mathrm{C} 2$ 時間インクベイトした. 次で飽和硫安液 0.4 $\mathrm{ml}$ を加えてよく振盪し， $0^{\circ} \mathrm{C}$ で20分間静置した後 $2,000 \mathrm{G} 15$ 分間遠沈し，上清 $0.5 \mathrm{ml}$ を Bray's scintillation solution $10 \mathrm{ml}$ のつた counting vial に入れ Aloka LSC-653 で放射能を測定した。抗血清の稀瀵倍数

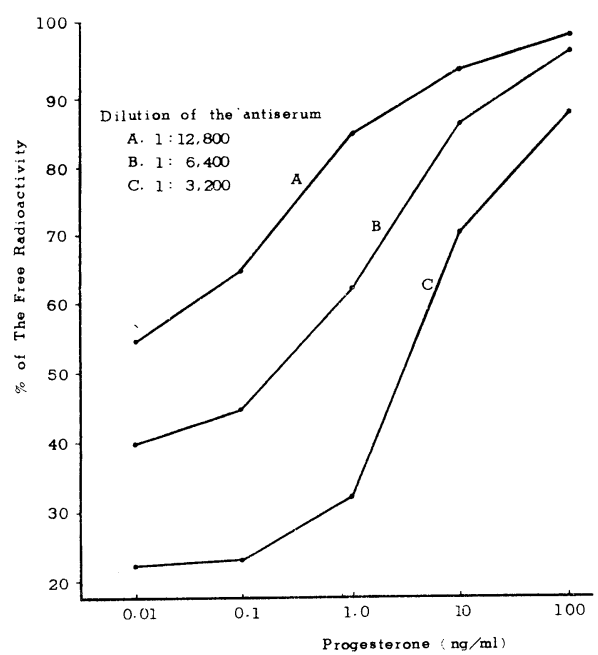

Fig. 1. Progesterone standard curves with various dilutions of antiserum. The sensitivity was $0.01 \mathrm{Ng} / \mathrm{ml}$, where a $1: 12,800$ diluted antiserum was employed.

Table 2. Cross-reaction of selected steroids with anti-progesterone-20-oxime-BSA antiserum

\begin{tabular}{|c|c|}
\hline Steroids & $\%$ Cross-reaction \\
\hline \multicolumn{2}{|l|}{$\mathrm{C}_{21}$ steroids } \\
\hline Progesterone & 100 \\
\hline 11-Desoxycorticosterone & 51.0 \\
\hline $20 \alpha$-Hydroxy-4-pregnen-3-one & 38.1 \\
\hline Pregnane-3, 20-dione & 20.0 \\
\hline $17 \alpha$-Hodroxy-4-pregnene-3, 20-dione & 8.0 \\
\hline $3 \alpha$-Hydroxypregnan-20-one & 0.7 \\
\hline Pregnane- $3 \alpha, 20 \alpha$-diol & $<0.1$ \\
\hline $3 \beta$-Hydroxy-5-pregnen-20-one & $<0.1$ \\
\hline Cortisol & $<0.1$ \\
\hline \multicolumn{2}{|l|}{$\mathrm{G}_{19}$ steroids } \\
\hline Testosterone & 14.4 \\
\hline 4-Androstene-3, 17-dione & 7.7 \\
\hline $3 \beta$-Hydroxy-5-androsten-17-one & 0.1 \\
\hline \multicolumn{2}{|l|}{$\mathrm{C}_{18}$ steroids } \\
\hline Estradiol & $<0.1$ \\
\hline Estriol & $<0.1$ \\
\hline
\end{tabular}


（対数目盛で表わす）を横軸に上清の放射能（free 型）を縌軸にとり，50\% free に相当する稀釈倍数を以て 抗血清の力価とした.

\section{2. 標準曲線及び他のステロイドの干渉}

P 測定の為の標準曲線（Fig. 1.）の作成は抗体価の決定の場合と全く同様の条件で行つた。即ち試験管に buffer $て て ~ 50 \mathrm{Ng} / \mathrm{ml}$ から $0.01 \mathrm{Ng} / \mathrm{ml}$ 迄段階稀釈した standard P $0.2 \mathrm{ml}$ の系列を作り, 稀釈した抗 P20-BSA $0.1 \mathrm{ml}$ と P-1, $2-{ }^{3} \mathrm{H} 0.02 \mu \mathrm{Ci}, 0.1 \mathrm{ml}$ を加え, $37^{\circ} \mathrm{C} 2$ 時間インクベイトした後硫安塩析法で free 型と bound 型を分離した。1：12,800 稀釈抗血清を使用した場合, P $10 \mathrm{Pg} / \mathrm{ml}$ は $0 \mathrm{Pg} / \mathrm{ml}$ と明らが区 別された．此の場合 P free での放射能結合率は48\%であつた。一方抗 P-20-BSA に対する P 以外のステロ

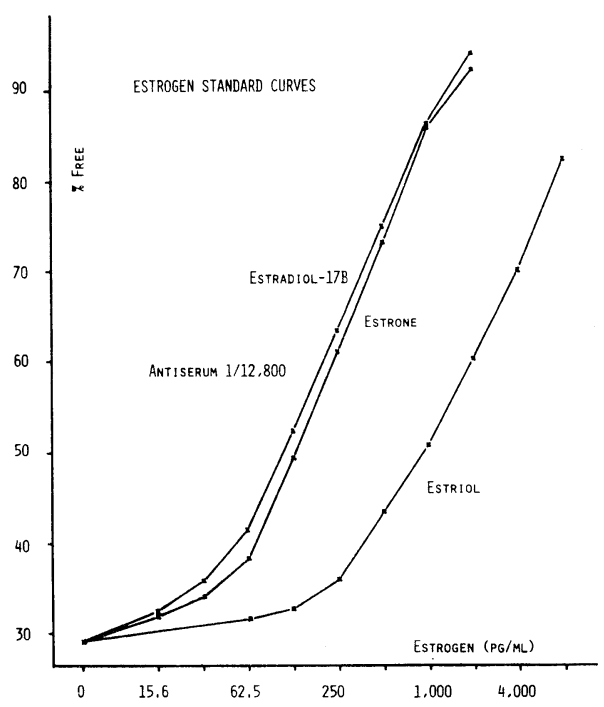

Fig. 2. Estrogen standard curves using a $1: 12,800$ dilution of anti-estradiol-17 $\beta$-succinyl-BSA antiserum. Estrone had almost the same affinity for the antiserum as estradiol-17 $\beta$.

Table 3. Separation of progesterone, estrone, and estradiol-17 $\beta$ from most markedly cross-reacting steroids by thin layer chromatography.

\begin{tabular}{l|c|c|c}
\hline \multicolumn{1}{|c|}{ Steroids } & $\mathrm{n}$ & $\mathrm{R}_{\mathrm{F}}$ & S.D. \\
\hline Pregnane-3, 20-dione & & 0.80 & \\
Progesterone & 15 & 0.73 & 0.012 \\
4-Androstene-3, 17-dione & & 0.65 & \\
11-Desoxycorticosterone & & 0.57 & \\
17 $\alpha$-Hydroxy-4-pregnene-3, 20-dione & & 0.55 & \\
Estrone & 15 & 0.54 & 0.009 \\
20 $\alpha$-Hydroxy-4-pregnen-3-one & & 0.53 & \\
Testosterone & & 0.51 & \\
Estradiol & 15 & 0.34 & 0.013 \\
Estriol & 15 & 0.07 & 0.007 \\
\hline
\end{tabular}

Solvent system : chloroform 19/ethanol 1

TLG plate : Baker-Flex Silica gel 1B, J.T. Baker Chemical Co. 
イドの交叉反応を調べる為 $\mathrm{G}_{21}$ ステロイドを中心に各種ステロイドの反応曲線を作成し，Abraham ${ }^{1)}$ の方法 に準じて \% cross-reaction を求めた (Table 2.). 其の結果抗 P-20-BSA 抗体は, P 以外に ${ }^{4} \Delta-3-k e t o s t e r o i d s$ との間に程度は様々であるが可成り広汎な交叉反応を有する事が判つた。 次に estrogen 標準曲線及び抗 $\mathrm{E}_{2}$ $17 \beta$-BSA に対する諸種ステロイドの交叉反応であるが，此れについては既に報告してあるので2)此処では簡 単に要点のみを述べる。抗 $\mathrm{E}_{2}-17-\mathrm{BSA}$ 抗体は， $\mathrm{E}_{2}$ 以外に $\mathrm{E}_{1}, \mathrm{E}_{3}$ 等の estratrienes と交叉反応を示すが， 其の他のステロイドとは殆んど反応を示さなかつた， $\mathrm{E}_{1}$ と $\mathrm{E}_{2}$ の反応性は略々同等であり，1：12,800 稀 釈抗血清を用いた時の測定感度は両者共 $15.6 \mathrm{Pg} / \mathrm{ml}$ (但し現在は $10 \mathrm{Pg} / \mathrm{ml}$ に調整）であつた (Fig. 2.). 以 上の事実から血漿中の $\mathrm{P}, \mathrm{E}_{1}, \mathrm{E}_{2}$ を此の RIA system で測定する為には，RIA に先立つて其れらを他の 交叉反応を示すステロイドから分離する必要性を認めた。

3. Thin layer chromatography (TLG) による血獎中 $\mathbf{P}, \mathbf{E}_{1}, \mathbf{E}_{2}$ の精製

Table 4. Procedure of the radioimmunoassay for plasma progesterone, estrone, and estradiol-17 $\beta$.

1) Pre-treatment of plasma samples

Plasma $1 \mathrm{ml}$

2,000dpm each of ${ }^{3} \mathrm{H}$-labeled $\mathrm{P}, \mathrm{E}_{1}$, and $\mathrm{E}_{2}$ added

Extracted with $10 \mathrm{ml}$ of ether

Evaporated

Dissolved in $2 \times 20 \mu 1$ of methanol and spotted on a thin layer plate

TLG (chloroform 19 : ethanol 1)

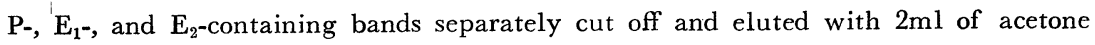

Evaporated

Dissolved in $0.5 \mathrm{ml}$ of buffer*1

$0.2 \mathrm{ml}$ for calculating recovery

$0.2 \mathrm{ml}$ for radioimmunoassay

2) Radioimmunoassay

*2 (Pre-treated sample or standard steroid

solution $\quad 0.2 \mathrm{ml}$

Diluted antiserum $\quad 0.1 \mathrm{ml}$

Tracer $\quad 0.1 \mathrm{ml}(0.02 \mu \mathrm{Ci})$

$37^{\circ} \mathrm{C}, 60 \mathrm{~min}$.

+Saturated ammonium sulfate $0.4 \mathrm{ml}$

$4^{\circ} \mathrm{C}, 20 \mathrm{~min}$.

Centrifuged $-2,000 \mathrm{G}, 4^{\circ} \mathrm{C}, 15 \mathrm{~min}$.

Supernatant $0.5 \mathrm{~m} 1$

$\downarrow$

Radioactivity counted

*1 $0.15 \mathrm{M}$ phosphate buffer, $\mathrm{pH} 7.4$, containing $2.5 \%$ ethanol

*2 two different assay system $-{ }^{3} \mathrm{H}-\mathrm{P}$ to anti-P system for measuring $\mathrm{P}$ and ${ }^{3} \mathrm{H}-\mathrm{E}_{2}$ to anti- $\mathrm{E}_{2}$ system for both $\mathrm{E}_{1}$ and $\mathrm{E}_{2}$ 
thin layer plate としては, 展開後の elution に便利な plastic sheets (Baker-Flex SilicaGel IB, J.T. Baker chemical Co., Phillisburg, N.J.) 号用いた。 種々の溶媒の組合せを用いて繰り返し展開実験を行つた 結果, chloroform/ethanol 19:1 が最適と考えられた. 此の溶媒系での各種ステロイドの $\mathrm{R}_{\mathrm{F}}$ 值を(Table 3.) に示す. 展開後, $\mathrm{P}, \mathrm{E}_{1}, \mathrm{E}_{2}$ 分画に相当する部分を縦 $0.8 \mathrm{~cm}$ 横 $2 \mathrm{~cm}$ に鉄で切り取り, アセトン $2 \mathrm{ml}$ で溶出した.

\section{4. 血獎中 $P, \mathbf{E}_{1}, \mathbf{E}_{2}$ の RIA}

以上の基礎実験の結果に基づいて RIA の procedure を（Table 4.）の如く定めた．此の表について少

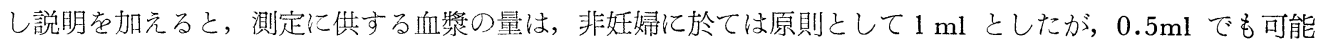
である。 incubation の時間は， 1 時閒と 2 時間で結果に余り差がなかつた為臨床検査に際しては 1 時間を 採用することとした，此の方法を用いて，pre-treatment に於ける回收率は約45〜80\%であつた。全操作に 要する時間は，5検体（15分画）以下ならば約 4 時間，50検体（150分画）で延べ約16時間であつた.

\section{TLG residue について}

前項に述べた方法で実際に臨床検体を測定したとしろ， $\mathrm{P}, \mathrm{E}_{1}, \mathrm{E}_{2}$ の何孔についても測定值が可成り 低い事に気付いた。此の free 型の radioactivity が予想以上に低くなる現象は, 抗血清を入れない control に於ても同じように見られた。 そこで pre-treatment の段階で検体中に混入した「何か」がRIA に於ける free 型と bound 型の分離比に影響を与えるのであろうと推定し，此の影響は謂ゆる processed standard curve (PSG) を作成するてとによつて事実上殆んど除き得るであろうと考えた。しかしながら PSC の作成 は実際の測定に当つて煩雑である為, 空の TLG plate に展開操作のみ加え $0.8 \mathrm{~cm} \times 2 \mathrm{~cm}$ に切り取つて アセトン $2 \mathrm{ml}$ で溶出し，此の TLG residue を含む試験管に標準ステロイド溶液を入れて RIA を行い標 準曲線を作成したところ, PSG に一致した曲線を得た為, 以後標準曲線の作成には此の方法を用いた. TLC residue 走加えた標準曲線に基づいて読みとつた測定值は従来の報告と極めてよく一致した. TLC residue のP標準曲線に及ぼす影響を（Fig. 3) に示す.

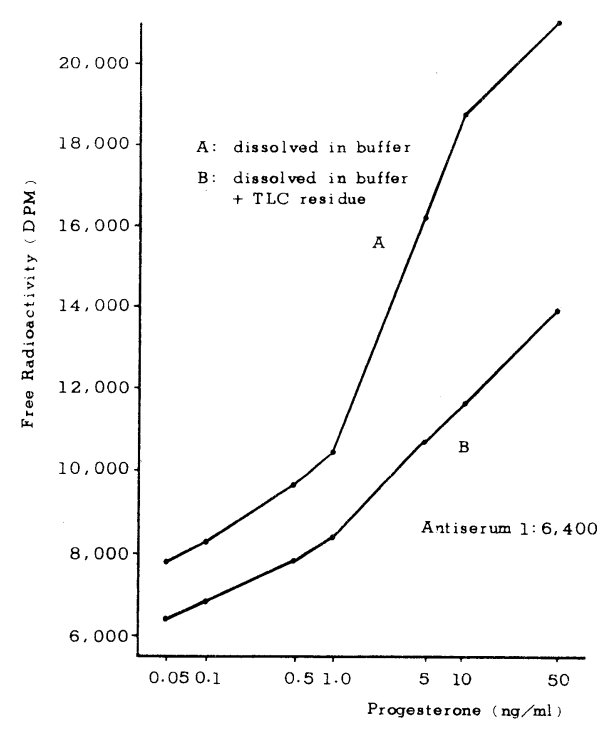

Fig. 3. Influence of TCL residue on progesterone standard curve. Remarkable decrease of the free radioactivity was observed.

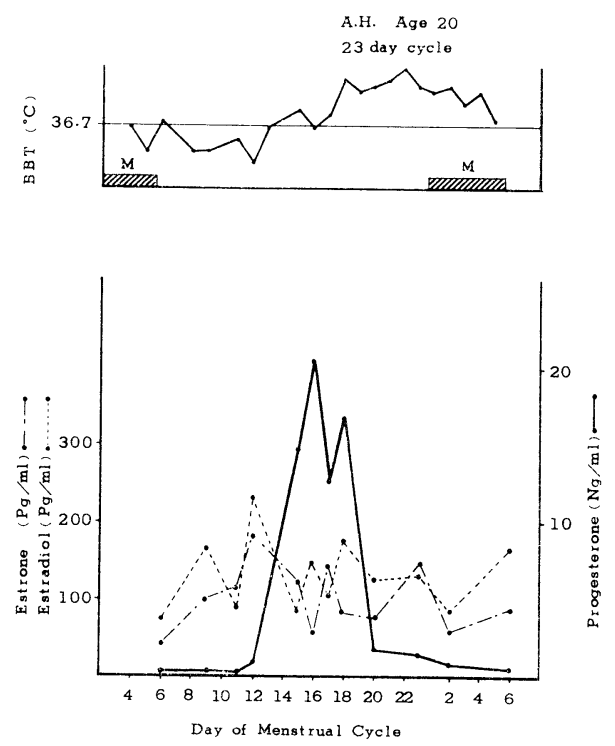

Fig. 4. Pattern of plasma estrogen and progesterone (1). 


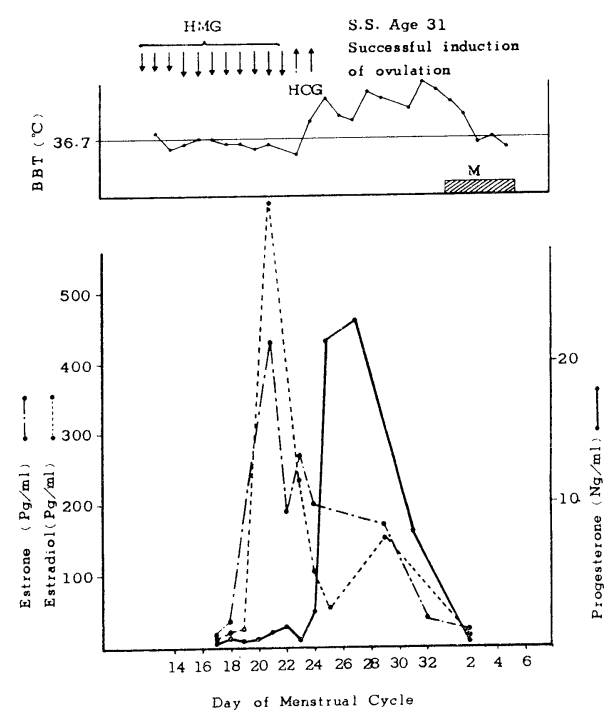

Fig. 5. Pattern of plasma estrogen and progesterone (2).

\section{6. 測 定 実 例}

非妊婦血漿中の $\mathrm{P}, \mathrm{E}_{1}, \mathrm{E}_{2}$ を経日的に測定したもののうち 2 例を示す. 第 1 例 (Fig. 4.) は 23 day cycle の婦人で， BBT は二相性である． $\mathrm{E}_{2}$ は月経周期第12日目（BBT の体温陥落日）に最高值 $235 \mathrm{Pg} / \mathrm{ml}$ とな り，其の後一旦低下し再び第18日目を中心に緩やかな上昇を示した． $\mathrm{E}_{1}$ は $\mathrm{E}_{2}$ に似た動きを示したが，周 期の後半に於て時に高い值となつた。此の婦人に於ては estrogen の分泌量が cycle を通じて比較的高值を 示すようである。 $\mathrm{P}$ 值は第12日目迄は $0.64 \mathrm{Ng} / \mathrm{ml}$ 以下であつたが，第 15 日目には $14.7 \mathrm{Ng} / \mathrm{ml}$ と急速に増 し第16日目に $22.5 \mathrm{Ng} / \mathrm{ml}$ の最高值となつた。第 2 例 (Fig. 5.) は第 2 度無月経に対し HMG (Humegon)HCG (Primogonyl) 療法を行つた例である. Humegon 2 vials $\times 6$ 日，3 vials $\times 7$ 日投与した時点で $\mathrm{E}_{2}$ は急速に上昇を示し， $631.3 \mathrm{Pg} / \mathrm{ml}$ と極めて高值となつた． HCG 3,000I.U. $\times 2$ 日投与後 $\mathrm{P}$ 值は $23.0 \mathrm{Ng} / \mathrm{ml}$ に 達し，排卵誘発に成功した事が推測された。尚此の症例は次回周期も HMG-HCG 投与を受け，其の際の 排卵で妊娠し，現在妊娠 4 ケ月である.

\section{考察}

competitive protein binding radioassay の出現は，従来のステロイド測定法に望み得なかつた高い測定 感度と大量姏理能力の両者を満足させる画期的方法として, 内分泌学臨床へのステロイド測定の実用化をも たらした．最近に至り，ステロイドを蛋白質に結合させて動物に免疫しステロイドに対する抗体を得るとと が可能となり，此れを用いた RIA が報告されるようになつた。 1)〜11) RIA は competitive protein binding assay の一種とも見做されるが，抗原抗体反応に基づくステロイドと抗体蛋白の結合は遙かに強力であり， 抗体の安定性と相俟つて routine の測定法には一層適していると考えられる. RIA が近い将来臨床に於ける ステロイド測定法として中心的役割を果すであろうと推測される今一つの根拠は，抗体の特異性を高める努

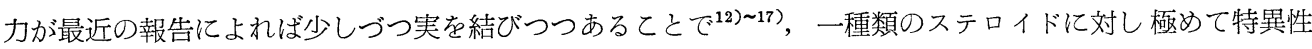
の高い抗体が出現すれば，R IA に先立つて精製操作を行う必要はなくなり至極簡単にステロイド測定が出 来るようになるからである。

著者はかかる時期に於ける過渡的方法として，抗血清の特異性の不十分な点を，検体の TLGによる前処 理で補い，現段階に於ける最も実用的な測定法の確立に意を注いだ. 其の結果, 非妊婦血漿 $1 \mathrm{ml}$ から 1 回 
の TLG 前処理で $P, E_{1}, E_{2}$ を一括して測定することに成功し，現在では 4 時間で 5 検体(15分画)，16時間 で50検体 (150分画) を処理するととが可能となつた．此の測定能力は臨床検査法としての条件を略々満足す るものと考える。本法を臨床に応用して得た多くのデーターについては稿を改めて発表する予定である.

謝辞 本研究の遂行に御協力いただきました名古屋大学医学部産婦人科学教室の諸先生に厚く感謝致しま す.併せて progesterone-20-oxime BSA conjugate を提供下さいました NIH に謝意を表します.

\section{文献}

1) Abraham, G.E. : J. Clin. Endocr., 29 : 866, (1969)

2）青木孝允：日内分泌誌，48：324，（1972）

3) Midgley, A.R., Jr., G.D. Niswender, and J. Sri Ram : Steroids, $13: 731$, (1969)

4) Mikhail, G., G.H. Wu, M. Ferin, and R.L. Vande Wiele : Steroids, $15: 333$, (1970)

5) Furuyama, S., D.M. Mayes, and C.A. Nugent : Steroids, $16: 415$, (1970)

6) Yoshizawa, I. and J. Fishman :

J. Clin. Endocr., $32: 3$, (1971)

7) Abraham,G.E., R.S. Swerdloff, D. Tulchinsky, and W.D. Odell : J. Clin. Endocr., $32: 619$, (1971)

8) Furuyama, S. and C.A. Nugent : Steroids, $17: 663$, (1971) 9) Abraham, G.E., R.S. Swerdloff, D. Tulchinsky, K. Hopper, and W.D. Odell : J. Clin. Endocr.,33: 42, (1971) 10) Aoki, T. and M.M. Hreshchyshyn : Am. J. Obstet. Gynecol., $111: 382$, (1971) 11) Tulchinsky, D., and G.E. Abraham : J. Clin.Endocr., $33: 775$, (1971)

12) Gross, S.J., J.D. Grant,R. Bennett, S-L.R. Wong, and P. Lomax : Steroids, $18: 555$, (1971)

13) Exley, D., M.W. Johnson, anu P.B.G. Dean : Steroids, $18: 605$, (1971)

14) Jeffcoate, S.L., and J.E. Searle : Steroids, $19: 181$, (1972)

15) Lindner, H.R., E. Perel, A. Friedlander, and A. Zeitlin : Steroids, $19: 357$, (1972) 16) Kuss, E. and R. Goebel : Steroids, $19: 509$, (1972)

17) Spieler, J.M., R.L. Webb, R.J. Saldarini, andJ.A. Coppola : Steroids, $19: 751$, (1972) 